\title{
Kemampuan Keluarga Dalam Merawat Orang Dengan Gangguan Jiwa Di Wilayah Kerja Puskesmas Tamansari Kota Tasikmalaya
}

\author{
Nia Restiana
}

\begin{abstract}
Abstrak
Gangguan jiwa merupakan respons maladaptif terhadap stressor yang berasal dari dalam maupun dari luar yang menimbulkan perubahan pada fungsi jiwa yang meliputi pikiran, perasaan dan prilaku yang menimbulkan ketidaknyamanan pada individu dan atau hambatan dalam melakukan kegiatan sosiall. Salah satu penyebab gangguan jiwa adalah konfliki keluarga. Keluarga merupakan unit kecil dan merupakan orang yang paling dekat dengan klien. Keluarga merupakan pemberi perawatan pertama bagi klien. Tujuan umum penelitian ini adalah menggambarkan kemampuan keluarga dalam merawat orang dengan gangguan jiwa. Sedangkan tujuan khusus penelitian ini adalah diketahuinya kemampuan keluarga dalam mengenal masalah, $\mathrm{k}$ mengambil keputusan, merawat, memodifikasi lingkungan, dan menggunakan fasilitas kesehatan. Desain penelitian yang digunakan adalah metode deskriptif dengan besarnya sampel 29 pasien. Penelitian ini diharapkan memberikan informasi mengenai kemampuan keluarga dalam merawat orang dengan gangguan jiwa, menjadi dasar pertimbangan dan pemikiran dalam mengembangkan perawatan untuk keluarga dalam merawat orang dengan gangguan jiwa dan dapat mengembangkan intervensi untuk meningkatkan kesehatan jiwa.
\end{abstract}

Kata kunci: kemampuan keluarga, gangguan jiwa

\section{Abstract}

Mental disorders are maladaptive responses to stressors originating from within or from outside which cause changes in mental functions that include thoughts, feelings and behaviors that cause discomfort to individuals and / or obstacles in carrying out social activities. One cause of mental disorders is family conflicts. The family is a small unit and is the person closest to the client. The family is the first care giver for the client. The general objective of this study is to describe the ability of families to care for people with mental disorders. While the specific purpose of this research is to know the ability of families to recognize problems, make decisions, care for, modify the environment, and use health facilities. The study design used was a descriptive method with a sample size of 29 patients. This research is expected to provide information on the ability of families to care for people with mental disorders, be a basis for consideration and thought in developing care for families in caring for people with mental disorders and can develop interventions to improve mental health.

Keywords: family ability, mental disorder

\section{PENDAHULUAN}

Kesehatan menurut UU No 36 Tahun 2009 adalah keadaan sehat baik secara fisik, mental, spiritual, maupun sosial yang memungkinkan setiap orang hidup produktif secara sosial maupun ekonomis.
Dengan demikian kesehatan bersifat holistik meliputi aspek bio psiko sosio spiritual, bukan hanya terbebas dari penyakit fisik tetapi kualitas hidup yang terdiri dari kesejahteraan dan kualitas 
hidup, sehingga kesehatan jiwa merupakan bagian integral dari kesehatan.

Kesehatan jiwa adalah keadaan sejahtera ditandai dengan perasaan bahagia, keseimbangan, merasa puas, pencapaian diri dan optimis (Stuart, 2009). Sehingga kesehatan jiwa merupakan bagian dari yang tidak dapat dipisahkan dari kesehatan dan keadaan sejahtera yang ditandai dengan dapat menyadari kemampuan yang dimiliki, dapat mengatasi stress, perasaan bahagia, merasa puas dan optimis sehingga seseorang dapat hidup harmonis dan produktif. Sumber yang dapat menimbulkan stress adalah kemampuan mengatasi stres dalam kehidupan, keadaan ekonomi yang rendah, tindakan kekerasan, timbulnya bencana alam seperti banjir, kebakaran, gunung merapi meletus, konflik di masyarakat, dan tidak bisa beradaptasi dengan perkembangan teknologi. Jika seseorang tidak bisa beradaptasi dengan keadaan tersebut maka akan memberikan respon maladaptif sehingga dapat menimbulkan masalah psikososial dan gangguan jiwa.

Menurut Towsend (2009) gangguan jiwa adalah kegagalan dalam memberikan respon terhadap stressor dari dalam maupun luar yang ditandai dengan ketidaksesuain pikiran, perasaan, prilaku merespon terhadap stressor dari lingkungan internal dan eksternal yang dibuktikan melalui pikiran, perasaan dan perilaku yang tidak sesuai dengan normanorma, budaya sehingga mengganggu dalam hubungan dengan orang lain. Sedangkan gangguan jiwa menurut Riskesdas (2013) adalah gangguan jiwa merupakan terganggunya kemampuan menilai realitas atau tilikan yang salah.

Prevalensi gangguan jiwa menurut data Riskesdas tahun 2007 sebesar 4,6\% sedangkan data Riskesdas tahun 2013 sebesar 1,7. Jumlah gangguan jiwa di Jawa barat 1,6\%. Dan jumlah gangguan jiwa di Kota Tasikmalaya ada 171 orang sedangkan di kecamatan Tamansari ada 32 orang. Penyebab masalah gangguan jiwa yang pasti belum diketahui namun ada beberapa factor penting yang mempengaruhi timbulnya gangguan jiwa. I Faktor yang mempengaruhi gangguan jiwa ini meliputi faktor biologi meliputi genetik, penyakit fisik, faktor psikologis seperti kepribadian, pengalaman masa lalu yang menyakitkan, faktor sosial budaya yaitu pendidikan, pekerjaan, status ekonomi dann lain lain.

Menurt Bostelman, dkk, 1994 (dalam Ice, 2009) menyatakan pada klien yang mengalami gangguan jiwa sering terjadi kekambuhan yang disebabkan karena ketidakpatuhan pengobatan, pelaksanaan program perawatan di rumah. (Bostelman, dkk, 1994). Keluarga merupakan unit kecil dan merupakan orang yang paling dekat dengan klien. Keluarga merupakan pemberi perawatan pertama bagi klien. 
Oleh sebab keluarga merupakan peran utama dalam memberikan perawatan yang diperlukan klien di rumah.

Penelitian ini bertujuan menggambarkan kemampuan keluarga dalam merawat orang dengan gangguan jiwa di wilayah kerja Puskesmas Tamansari, selain itu juga penelitian ini bertujuan untuk mengenal masalah gangguan jiwa, mengambil keputusan, merawat orang dengan gangguan jiwa, memodifikasi lingkungan dan menggunakan fasilitas kesehatan di wilayah Kerja Puskesmas Tamansari.

\section{METODE PENELITIAN}

Desain penelitian yang digunakan adalah metode deskriptif. Penelitian ini dilakukan selama 1 tahun. Penelitian dilaksanaka untuk mendapatkan gambaran kemampuan keluarga dalam merawat orang dengan gangguan jiwa di Wilayah Kerja Puskesmas Tamansari. Besarnya ukuran sampel adalah 29 orang keluarga. Analisis statistik yang digunakan yaitu univariat yaitu proporsi dalam bentuk tabel dan distribusi frekuensi.

\section{HASIL DAN PEMBAHASAN}

\section{Hasil Penelitian}

Hasil penelitian yang dilakukan di Wilayah kerja Puskesmas Tamansari Tasikmalaya, mulai bulan Januari sampai dengan Desember 2018, dengan besarnya ukuran sampel 29 orang keluarga. a. Kemampuan Keluarga Dalam Merawat Orang Dengan Gangguan Jiwa Gangguan Jiwa

Tabel 1 Kemampuan keluarga dalam merawat orang dengan gangguan jiwa

\begin{tabular}{|c|c|c|}
\hline $\begin{array}{c}\text { Kemampuan } \\
\text { Keluarga }\end{array}$ & Jumlah & $\begin{array}{c}\text { Persentase } \\
(\%)\end{array}$ \\
\hline $\begin{array}{l}\text { 1. Mengenal } \\
\text { Maslah }\end{array}$ & & \\
\hline - Mampu & 12 & 41,4 \\
\hline $\begin{array}{l}\text { - } \quad \text { Tidak } \\
\text { Mampu }\end{array}$ & 17 & 58,6 \\
\hline
\end{tabular}

2. Mengambil keputusan

- Mampu $12 \quad 41,4$

- Tidak $17 \quad 58,6$
Mampu

3. Merawat orang dengan gangguan jiwa

- Mampu 17 58,6

- Tidak

1241,4

4. Memodifikasi lingkungan

$\begin{array}{llll}\text { - } & \text { Mampu } & 18 & 62,1 \\ \text { - } & \text { Tidak } & 11 & 37,9 \\ \text { Mampu } & & \end{array}$

5. Menggunaka $\mathrm{n}$ fasilitas kesehatan

- Mampu

$$
18
$$

- Tidak 11 37,9 Mampu

Sumber: Hasil penelitian tahun 2018

Berdasarkan Tabel 1, kemampuan keluarga dalam merawat orang dengan gangguan jiwa di wilayah kerja Puskesmas Tamansari yang meliputi kemampuan keluarga dalam mengenal masalah, mengambil keputusan, merawat anggota keluarga dengan gangguan jiwa, memodifikasi lingkungan dan menggunakan fasilitas kesehatan. Kemampuan dalam mengenal masalah 
sebagian besar tidak mampu yaitu 17 orang (58,6\%). Kemampuan dalam mengambil keputusan sebagaian besar tidak mampu yaitu 17 orang $(58,6 \%)$. Kemampuan dalam merawat orang dengan gangguan jiwa sebagian besar mampu yaitu 17 0rang (58,6\%). Kemampuan dalam memodifikasi lingkungan sebagian besar mampu yaitu 18 orang yaitu $(61,2 \%)$. Dan kemampuan dalam menggunakan fasilitas kesehatan sebagian besar mampu yaitu 18 orang yaitu $(61,2 \%)$.

\section{Pembahasan}

Sebagian besar kemampuan dalam mengenal masalah adalah tidak mampu yaitu 17 orang $(58,6 \%)$. Hal ini disebabkan karena stigma yang buruk menganggap bahwa gangguan jiwa ini penyakit keturunan dan tidak dapat disembuhkan. Sehingga dengan stigma tersebut mempengaruhi keluarga dalam mengenal maslah. Dan selain stigma juga dipengraruhi oleh pendidikan yang rendah, sebagian besar pendidikan keluarga yang merawat berpendidikan rendah dan hal ini mempengaruhi dalam kemampuan keluarga dalam mengenal masalah. Hal ini disebabkan karena kurangnya informasi tentang gangguan jiwa. Menurut Notoatmodjo (2010) menyatakan bahwa bahwa banyaknya informasi dapat memengaruhi atau menambah pengetahuan seseorang dan dengan pengetahuan dapat menimbulkan kesadaran seseorang dalam berperilaku sesuai dengan pengetahuan yang dimilikinya serta cara memelihara kesehatan termasuk bagian dari pengetahuan kesehatan.

Kemampuan keluarga dalam mengambil keputusan sebagaian besar tidak mampu yaitu 17 orang $(58,6 \%)$. Hal ini disebabkan karena kemampuan dalam mengenal masalah kurang sehingga mempengaruhi dalam mengambil keputusan. Keluarga mengambil keputusan jika pasien membahayakan keluarga maupun lingkungannya. Kemampuan keluarga dalam merawat orang dengan gangguan jiwa sebagian besar mampu yaitu 17 0rang (58,6\%). Keluarga akan melakukan perawatan jika anggota keluarga yang mengalami gangguan jiwa membahayakan, jika tidak membahayakan akan dibiarkan. Keluarga jarang berinteraksi dengan anggota keluarga yang mengalami gangguan jiwa karena bicaranya tidak nyambung, dan takut dimarahi sehingga dibiarkan saja asal tidak membahayakan. Dan keluarga juga mengatakan tidak harus diobati karena penyakit ini tidak dapat sembuh sehingga pasien tidak diberikan pengobatan. Dan ada juga keluarga yang mengatakan bahwa penyakit ini adalah penyakit kiriman sehingga tidak perlu diobati kepada tenaga kesehatan tapi cukup ke orang pintar. Dan dalam memberikan perawatan jarang memberikan pujian jika anggota keluarga sudah dapat menyelesaikan pekerjaannya. 
Padahal memberikan pujian merupak hal penting untuk meningkatkan kepercayaan orang mengalami gangguan jiwa karena merasa diharga, diberi dukungan dan dihormati.

Kemampuan dalam memodifikasi lingkungan sebagian besar mampu yaitu 18 orang yaitu $(61,2 \%)$. Hal ini disebabkan keluarga mempunyai pengalaman ketika pasien mengamuk maka barang barang yang membahayakan pasien harus diamankan. Tetapi ada juga pasien yang masih diasingkan dari keluarganya, pasien tinggal di rumah terpisah dengan keluarganya karena pasien sering mengamuk. Kemampuan keluarga dalam merawat dipengaruhi juga oleh motivasi keluarga dalam orang dengan gangguan jiwa.

Kemampuan keluarga dalam menggunakan fasilitas kesehatan sebagian besar mampu yaitu 18 orang yaitu $(61,2 \%)$. Keluarga menggunakan fasilitas kesehatan karena ia memiliki kartu BPJS sehingga ia berobat ke layanan kesehatan. Tapi ada juga yang sudah memiliki kartu BPJS tidak mau menggunakan fasilitas kesehatan karena jarak yang jauh antara rumah dan fasilitas kesehatan. Dan keluarga mengatakan walaupun ke pelayanan kesehatan tidak bayar tetapi ia harus membayar akomodasinya. Ada sebagian tidak menggunakan fasilitas kesehatan karena tidak mempunyai kartu BPJS dan ada juga yang menganggap bahwa pasien kemasukan sehingga tidak perlu dibawa ke fasilitas kesehatan. Tetapi dibawa ke orang pintar. Faktor ekonomi, pendidikan mempengaruhi juga kemampuan keluarga dalam menggunakan fasilitas kesehatan. Hal ini sesuia dengan hasil penelitian Suryenti, 2017 yang menyatakan bahwa dari segi dukungan instrumental keluarga kurang bertanggung jawab atas perawatan anggota keluarga serta kurang membimbing anggota keluarga untuk segera berobat jalan jika menunjukkan tanda dan gejala kekambuhan. Padahal dukungan instrumental sangat penting dalam melakukan perawatan pada orang dengan gangguan jiwa

\section{KESIMPULAN DAN SARAN}

\section{Kesimpulan}

Kemampuan Keluarga Dalam :

a. Mengenal masalah sebagian besar tidak mampu yaitu 17 orang $(58,6 \%)$.

b. Mengambil keputusan sebagaian besar tidak mampu yaitu 17 orang $(58,6 \%)$.

c. Merawat keluarga yang mengalami gangguan jiwa sebagian besar mampu yaitu 17 0rang (58,6\%).

d. Memodifikasi lingkungan sebagian besar mampu yaitu 18 orang yaitu (61,2\%).

e. Menggunakan fasilitas kesehatan sebagian besar mampu yaitu 18 orang yaitu $(61,2 \%)$.

\section{Saran}

a. Dasar pertimbangan dan pemikiran dalam mengembangkan perawatan 
untuk keluarga dalam merawat orang dengan gangguan jiwa.

b. Mengembangkan intervensi untuk meningkatkan kesehatan jiwa.

1. Fakultas Ilmu Kesehatan Universitas Muhammadiyah Tasikmalaya

Email:nia.restiana@umtas.ac.id

DAFTAR PUSTAKA

Notoatmodjo (2010) Promosi Kesehatan Dan Ilmu prilaku. Rineka Cipta:Jakarta

Riset Kesehatan Dasar (2007) https://www.k4health.org/sites/defa ult/files/laporanNasional\%20Riskes das\%202007.pdf

Riset Kesehatan Dasar (2013) http://www.depkes.go.id/resources/ download/general/Hasil\%20Riskes das\%202013.pdf
Suyetni,. Dukungan Dan Beban Keluarga Dengan Kemampuan Keluarga Merawat Pasien Resiko Preilaku Kekerasan Di Klinik Jiwa Rumah Sakit Jiwa Provinsi Jambbi 2017. Jurnal Psikologi Jambi Volume 2 No 2 Oktober 2017 p-ISSN : 25282735 e-ISSN:2580-7021

Stuart,G.W (2009). Principles and Practice of psychiatric nursing. St Louis: Mosby

Townsend, C.M. (2009). Essentials of Psychiatric Mental Health Nursing. Philadelphia: F.A. Davis Company

UU Kesehatan No 36 Tahun 2009. http://pdui.org/unduhan/UU\%2036 $\% 202009 \% 20$ Kesehatan.pdf 